Creative Commons User License: CC BY-NC-ND

Abstracted by: EBSCOhost, Electronic Journals Service (EJS), Google Scholar, Journal Seek, Scientific Commons,

Food and Agricultural Organization (FAO), CABI and Scopus

http://eoi.citefactor.org/10.11226/v24i4
Journal of Agricultural Extension

Vol. 24 (4) October, 2020

ISSN(e): 24086851; ISSN(Print); 1119944X

http://journal.aesonnigeria.org

http://www.ajol.info/index.php/iae

Email: editorinchief@aesonnigeria.org

\title{
Strategic Planning Approach to the Development of Contract Farming in the Egyptian Sugar Industry \\ https://dx.doi.org/10.4314/jae.v24i4.17
}

\author{
Hazem S. Kassem \\ Department of Agricultural Extension and Rural Society, King Saud University, Saudi Arabia \\ Email: hskassem@ksu.edu.sa \\ +966581045671
}

\section{Bader Alhafi Alotaibi}

Department of Agricultural Extension and Rural Society, King Saud University, Saudi Arabia Email:balhafi@ksu.edu.sa

+966504240201

\section{Salim Bagadeem}

Faculty of Business Administration, Arab Open University, Saudi Arabia

Email: bagadeem@arabou.ksu.edu

$+966503360522$

\section{Abstract}

The strategies required to develop contract farming in the Egyptian sugar industry were examined by applying the Strength-Weakness-OpportunitiesThreats (SWOT) approach in combination with an analytic hierarchy process. Data were collected from sugar beet farmers, extension workers, experts, and employees of the Dakhalia Sugar and Refining Company in Egypt. Market risk has the highest overall priority score among the strengths. Noncommitment of farmers to harvest time received the highest overall priority score among the weaknesses, while valorization of sugar industry wastes had the highest overall priority score among the opportunities, and accumulation of large reserves of sugar at the factory was perceived as the most important threat to the sugar industry. These findings can be used to formulate strategies based on current situation analysis and create suitable conditions for successful contract farming in the sugar sector.

Key words: strategies; SWOT-AHP; contract farming; sugar industry; Egypt.

\section{Introduction}

Sugar forms an essential part of the human diet as a source of energy, sweeteners and preservatives (DiNicolantonio and Berger, 2016). Sugar crops, such as sugarcane, sugar beet, corn, sorghum, and cassava, are the main sources of sugar and other sugar products (Rajaeifar, Hemayati, Tabatabaei, Aghbashlo, and Mahmoudi, 2019). Sugar production has become one of the most developed industries in the agri-food sector in recent years (Food and Agriculture Organization of the United Nations, 2017). The sugar industry is not limited to producing sugar only, but also produces several by-products, such as biomass, bagasse, and molasses, which can be used for producing electricity, fuel, paper, and organic 
chemicals (Eggleston and Lima, 2015). Asia's share in global sugar production in 2018-19 was 77 million tons, followed by South America (38 million tons) and Europe (27 million tons). Brazil, India, EU, Thailand, China, and the US accounted in 2018 for more than $50 \%$ of the world's total sugar production (FAO, 2019). According to United States Department of Agriculture report (USDA, 2019), most of the sugar is of sugarcane origin $(77.5 \%)$, while the rest $(22.5 \%)$ is contributed by sugar beet.

Egypt, along with the US, China, Morocco, Iran, Japan, and Pakistan, produces sugar from both sugar cane and sugar beet (FAOSTAT, 2017). The total sugar production (excluding imports) in Egypt in 2018-19 was 2.4 million tons, amounting to $1.3 \%$ of the global sugar production and $20 \%$ of the total sugar production in Africa. Of this, 1.3 million tons were derived from sugar beet while 1.1 million tons came from sugarcane (Omar, 2019). Based on the report of the Ministry of Agriculture and Land Reclamation (MALR, 2019), in 2018-19, the area under sugar beet and sugarcane cultivation was 245,000 hectares and 142,000 hectares, respectively, representing around $10 \%$ of the total agricultural land, with an average production of 45 tons of sugar beet and 110 tons of sugar cane per hectare. The total sugar consumption in 2018 was about 3.2 million tons, indicating that the selfsufficiency rate is about 75\%. According to Omar (2019), there are 15 sugar factories in Egypt - seven processing sugarcane, seven processing sugar beets, and one processing both. Of these, nine are state-run companies affiliated with the Ministry of Supply and Industrial Trade, three are in the private sector, and three are of publicprivate ownership.

To promote sustainable investment in the sugar industry, sugar processors are encouraged to form partnerships with farmers based on contract agreements (Ragasa, Lambrecht, and Kufoalor, 2018). Contract farming has become a popular model and is the only marketing channel for sugar crop farmers to engage with sugar processors (Biely, Creemers, Van Passel, and Mathijs, 2018). Contract farming is a form of vertical coordination that includes forming an agreement between farmers and a food processing/marketing firm by which the firms support farmers during production and/or post-harvest by providing them with improved access to highquality inputs, advisory support, storage facility, and marketing services (Khan, Nakano, and Kurosaki et al., 2019; Soullier and Moustier, 2018).

Several studies have indicated a positive social and economic impact of contract farming for farmers (Ba, de Mey, Thoron, and Demont, 2019; Lambrecht and Ragasa, 2018; Soullier and Moustier, 2018). It enhances farmers' productivity by providing them with high-yielding seeds and extension services, promotes farmers' participation in the agricultural value chain, minimizes transaction costs, reduces both input and output price risks, and boosts quality standards implementation (Soullier and Moustier, 2018; Ragasa et al., 2018; Ton, Vellema, Desiere, Weituschat, and D'Haese, 2018). Nevertheless, contract farming has several disadvantages, such as exclusion of small-scale farmers, increased risk of loss of autonomy, weak negotiation power, lower selling prices in comparison to the price after harvest, over-indebtedness in case of insufficient consideration of the livelihood framework/farm assets, increase in farmers' exposure to risks from compliance with new techniques, and weak claiming position in case of buyer default (Ba et al., 2019; Lambrecht and Ragasa, 2018; Ze-ying, Ying, Di, Chen, and Ji-min, 2018). 
Sustaining a conducive environment for contract farming schemes in the sugar sector depends on the ability to manage the nexus between farmers, ecosystem, and the availability of physical resources ( $Y u$ and $\mathrm{Wu}, 2018$ ). Hence, there are increasing demands for a broader engagement of the relevant stakeholders in developing strategies for the management of the sugar industry (Biely et al., 2018), which would help in identifying the barriers to the growth of contract services provided by the companies as well as in understanding how the internal and external environment affects the effectiveness and competitiveness of the company (Ba et al., 2019). The internal and external environment are described using the StrengthsWeakness-Opportunities-Threats (SWOT) analysis (Szulecka and Zalazar, 2017). Due to the increased complexity of agribusiness and the alternative methods of management, companies often encounter difficulties in selecting and adopting new strategies (Abdollahzadeh, Damalas, Sharifzadeh, and Ahmadi-Gorgi, 2016). The analytic hierarchy process (AHP) has been widely applied as a support tool for solving such complex decision problems (Gottfried, De Clercq, Blair, Weng, Wang et al., 2018). AHP provides a framework for assessing the decision alternatives from among a set of potential solutions to a problem (Etongo, Kanninen, Epule, and Fobissie, 2018). Accordingly, the use of a combined SWOT-AHP tool is very useful in improving multi-criteria decision making and for developing policies (Omobepade, Adebayo, and Amos, 2019).

A review of the literature reveals that there is a lack of in-depth analysis of contract farming within the sugar industry to develop appropriate policies. Hence, this study provides a decisive analysis of the contract farming schemes in the sugar sector. The objectives are to: (1) identify the strengths, weaknesses, opportunities, and threats of the company under investigation; and (2) determine the importance of these factors for investment in the sugar industry.

\section{Methodology}

The Dakhalia Sugar and Refining Company (DSRC) is a public entity established in 1992 and is engaged in extracting sugar from beets, refining raw sugar, and producing molasses. Its factory is in the Belqas district of Dakhalia governorate in Northeast Egypt $\left(31.1400^{\circ} \mathrm{N}, 31.2200^{\circ} \mathrm{E}\right)$ and is one of the biggest sugar factories in the Middle East and Africa with an authorized capital of US\$300,000. The maximum capacity of the factory is 2,500,000 tons/year. In 2018-19, 2,331,245 tons of sugar beet weresupplied and 317,688 tons of sugar were produced. Furthermore, it has 9122 contract farmers, representing $87.3 \%$ of sugar beet farmers in the Dakhalia governorate (DSRC, 2019).

The company runs a beet sugar contract farming scheme to obtain beets for processing. The company's extension agents come to an arrangement with farmers interested in contracting, even before cultivation begins. If a farmer agrees, a written contract is drawn up between the farmer and the company, which specifies the area to be cultivated (hectares) and the price/ton according to the percentage of sugar in the sample taken from the beets at the time of delivery. The company provides free access to rent on machinery, transportation, and extension services. Furthermore, it provides credit for farm inputs (seeds, fertilizers, and pesticides) to the contracting farmers as consignment goods, deducting their prices from the total amount to be paid at the end of the season. The farmers receive full payments every season. 
SWOT analysis is commonly used in an organization's strategic planning process to study its internal (strengths and weaknesses) and external environment (opportunities and threats) in achieving its mission (Etongo et al., 2018). By identifying the factors in the four categories, the organization can analyze the current situation and develop future strategies (Phadermrod, Crowder, and Wills, 2019). AHP is a structured technique for analyzing complex decisions. It supports SWOT analysis by assigning relative priority to each factor. Synthesizing the priorities enables decision makers to select the most important strategies for the problem under investigation (Polat, Alkan, and Sürmeneli, 2017).

The main steps in the strategic planning of DSRC's contract farming scheme using SWOT-AHP methodology are summarized as follows:

\section{Step 1. Identification of the SWOT sub-factors}

The SWOT approach is used to investigate the factors affecting the sustainability of the company's contract farming scheme. These factors are derived from a literature assessment. A pilot study is conducted with the main stakeholders of the contract farming scheme: farmers, field extension workers, and company employees. The criteria for the interview was pre-determined to obtain adequate results: (a) at least 5 years of working experience in the company (extension workers and employees) or five years of contracting with the company (farmers); (b) knowledge in the field of contract farming; (c) represent different departments (financial, technical, inspection...etc.) related to different operations in the sugar beet value chain; and (d) answer questions accurately. The population comprises of all contracting farmers in Belqas district $(n=603)$, all extension workers employing in the DSRC $(n=39)$, and mangers of all departments of the company $(n=16)$. Based on this, detailed questions were posed to a random sample of 120 contract farmers representing around $5 \%$ of the total population. Additionally, all extension workers and managers were targeted for data collection. Due to different circumstances of the respondents, we collected data from 30 extension workers, and 14 employees to identify the SWOT factors. The respondents identified 58 SWOT factors. Although there is no rule regarding the number of SWOT sub-factors, it is recommended that it should not exceed 10 in each category (Polat et al., 2017).

To reduce the number of factors to suite the AHP criteria, only those factors mentioned by more than $50 \%$ of the stakeholders were included in the initial phase of SWOT factor identification, which identified 36 factors (10 strengths, 8 weaknesses, 12 opportunities, and 6 threats). A focus group was conducted with managers of eight departments; agriculture, finance, production, legal affairs, transportation, industrial control, engineering, and information systems. Those mangers were chosen because of their experience with different company operations. The focus group discussion started with a short presentation explaining the purpose of the meeting. The mangers were then asked to assess the importance and impact level of each issue on a 5-point Likert-type scale (5 being very high and 1 being very low). The priority of each statement was measured by calculating the weighted mean as follows: Weighted mean = Importance $*$ Impact. All items with a high mean $(\geq 20)$ were selected in the final draft of SWOT factors (22 sub-factors). 


\section{Step 2. Developing the AHP hierarchy}

The first step in AHP is the decomposition of a specific issue into a hierarchical structure with the main goal defined at the upper level of the structure (Polat et al., 2017). The goal is then broken into strategic objectives in accordance with the SWOT analysis; strengths (S), weaknesses (W), opportunities (O), and threats $(T)$. Each factor is then classified into sub-factors (S1, S2, ...Sn). Following the same method, sub-factors are divided to alternatives (A) at the bottom level of the structure as illustrated in Figure 1.
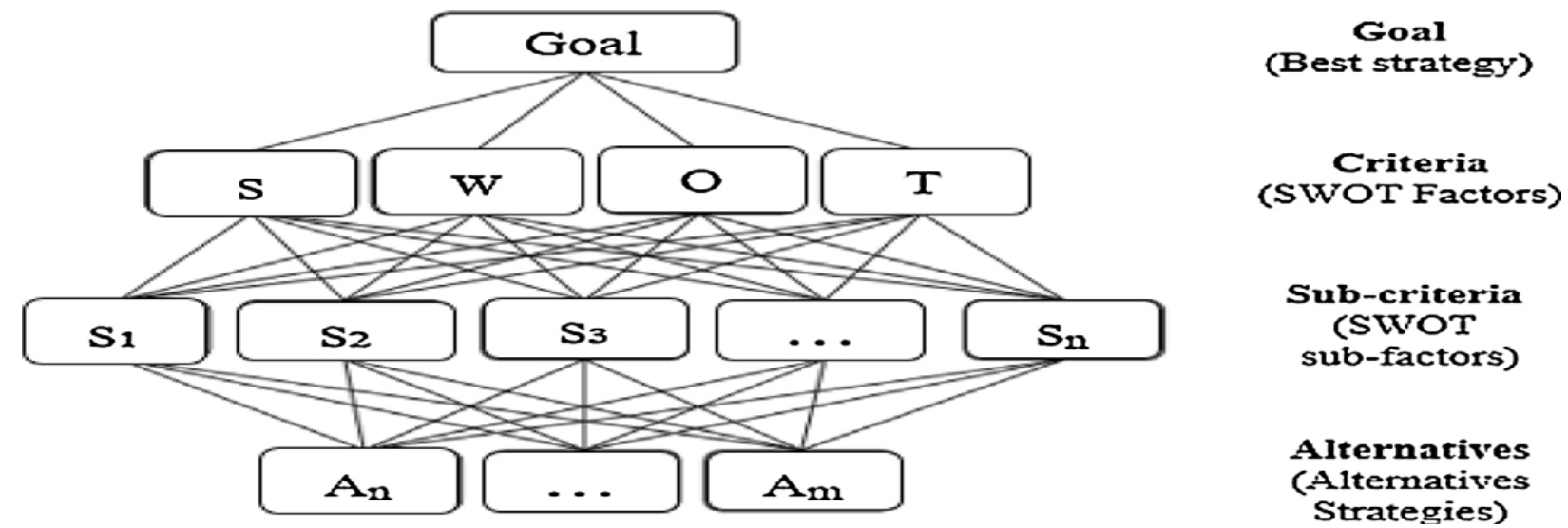

Figure 1: The hierarchical structure of the SWOT model

Alternatives

(Alternatives Strategies)

\section{Step 3. Performing pairwise comparisons}

To evaluate the factors separately for each SWOT category, another focus group discussion was held with four academic professionals and four representatives from the company headquarters. The participants were asked to assess the more important of the two factors being compared, using a nine-point scale as depicted in Table 1(Mu and Pereyra-Rojas, 2017). The comparisons are used to make a reciprocal matrix expressing the relative values of a set of attributes.

\section{Table 1: Scales for pairwise comparison}

\begin{tabular}{|c|c|}
\hline $\begin{array}{l}\text { Intensity of } \\
\text { Importance }\end{array}$ & Explanation \\
\hline 1 & Two criteria contribute equally to the objective. \\
\hline 3 & Experience and judgment slightly favor one over the other. \\
\hline 5 & Experience and judgment strongly favor one over the other. \\
\hline 7 & $\begin{array}{l}\text { One criterion is strongly favored and its dominance is demonstrated in } \\
\text { practice. }\end{array}$ \\
\hline 9 & $\begin{array}{l}\text { Importance of one criterion over another is affirmed on the highest } \\
\text { possible order. }\end{array}$ \\
\hline $2,4,6,8$ & Used to represent a compromise between the priorities listed above. \\
\hline
\end{tabular}

\section{Step 4. Determining the priorities of the SWOT factors}

The Eigen value method was used to calculate the relative weights of the elements in each pairwise comparison matrix. The Eigen vector $(\lambda \max )$ was computed from first totaling each column in the matrix and then dividing each element of the matrix by its column total. Next, the average value of the row elements are calculated to normalize the Eigen vector.

The relative weights $(\mathrm{W})$ of matrix $(\mathrm{A})$ are obtained from the following formula: 


\section{$(A-\lambda \max \mathrm{I}) \mathrm{xW}=\mathrm{o}$}

where $\mathrm{I}=$ unit matrix and $\lambda \max =$ the biggest Eigen value of matrix $\mathrm{A}$.

The consistency index $(\mathrm{Cl})$ is calculated to ensure the judgment of the decision makers is

consistent with respect to the comparison $n$ matrix as shown in the following equation:

$C I=\frac{(\lambda \max -n)}{(n-1)}$

The consistency ratio (CR) depends on the consistency index $(\mathrm{Cl})$ and random index (RI) presented as follows (Mu and Pereyra-Rojas, 2017):

$C R=\frac{C I}{R I}$

According to Table 2, $\mathrm{RI}$ is determined based on the number of criteria $n$ [31]. Accordingly, the matrix will be consistent and acceptable if $\mathrm{CR} \leq 0.1$. If the consistency ratio increases by 0.1 , the process is repeated and a reasonable value of the consistency rate is obtained.

Table 2: Random Index (RI)

\begin{tabular}{|c|c|c|c|c|c|c|c|c|c|c|c|c|c|c|c|}
\hline$n$ & 1 & 2 & 3 & 4 & 5 & 6 & 7 & 8 & 9 & 10 & 11 & 12 & 13 & 14 & 15 \\
\hline$\overline{\mathrm{Rl}}$ & 0.00 & 0.00 & 0.58 & 0.9 & 1.12 & 1.24 & 1.32 & 1.41 & 1.45 & 1.49 & 1.51 & 1.54 & 1.56 & 1.57 & 1.59 \\
\hline
\end{tabular}

\section{Step 5. Calculating the global (overall) importance degrees of the SWOT sub- factors}

The global (overall) importance is computed using the following formula ( $\mathrm{Mu}$ and Pereyra-Rojas, 2017):

$$
\text { Wsubfactors }(\text { global })=\text { Wfactors X Wsubfactors (local) }
$$

where Wsubfactors (global) is a matrix that denotes the global importance degrees of the SWOT sub-factors, Wfactors is a matrix that denotes the priorities of the SWOT factors, and Wsubfactors (local) is a matrix that denotes the local importance degrees of the SWOT sub-factors.

Step 6. Calculating the overall priorities of the alternative strategies

The overall priorities of the alternative strategies are determined as follows (Polat et al., 2017):

Walternatives $=W 1 X$ Wsubfactors

where $\mathrm{W} 1$ is a matrix that denotes the importance degrees of the alternative strategies with respect to each SWOT sub-factor.

\section{Results and Discussion}

\section{Situational Assessment (SWOT analysis)}

The final draft of the SWOT matrix comprises 22 sub-factors: six strengths, five weaknesses, six opportunities, and five threats as shown in Table 3. 


\section{Table 3: SWOT matrix}

\begin{tabular}{|c|c|}
\hline Strengths (S) & Weaknesses (W) \\
\hline S1: $\begin{array}{r}\text { Reduced market risk due to forward } \\
\text { contracting }\end{array}$ & W1: Non-commitment of farmers to harvest time \\
\hline $\begin{array}{l}\text { S2: Improved liquidity through adequate terms of } \\
\text { payment }\end{array}$ & $\begin{array}{l}\text { W2: High infrastructure and transaction costs vis-a- } \\
\text { vis stable or decreasing sugar price }\end{array}$ \\
\hline $\begin{array}{l}\text { S3: Reduced price risk due to pre-agreed prices or } \\
\text { price calculation formula }\end{array}$ & $\begin{array}{l}\text { W3: Delay in transportation of sugar beet after } \\
\text { harvest }\end{array}$ \\
\hline $\begin{array}{l}\text { S4: Improved access to inputs through company } \\
\text { credit or direct provision (seeds, fertilizers, } \\
\text { pesticides, machinery) }\end{array}$ & $\begin{array}{l}\text { W4: Lack of regular contact between extension staff } \\
\text { and farmers }\end{array}$ \\
\hline S5: Improved access to advisory services & $\begin{array}{l}\text { W5: Weak claiming position in case of unduly high } \\
\text { rejection rates or late payment }\end{array}$ \\
\hline \multicolumn{2}{|l|}{$\begin{array}{l}\text { S6: Reduced transaction costs (transportation of } \\
\text { the crop by the factory) }\end{array}$} \\
\hline Opportunities (0) & Threats (T) \\
\hline $\begin{array}{l}\text { 01: Access to new varieties (high-yield and } \\
\text { resistant to diseases) }\end{array}$ & $\begin{array}{l}\text { T1: Ensuring sustainable production due to } \\
\text { increasing production costs after change to } \\
\text { floating currency }\end{array}$ \\
\hline $\begin{array}{l}\text { O2: Sustainable plan considers factory capacity, } \\
\text { increasing number of farmers, decreasing } \\
\text { production costs }\end{array}$ & $\begin{array}{l}\text { T2: Accumulation of large sugar reserves due to } \\
\text { fixed government price }\end{array}$ \\
\hline $\begin{array}{l}\text { O3: Design mechanisms for managing conflict with } \\
\text { farmers }\end{array}$ & $\begin{array}{l}\text { T3: Lack of competitiveness compared to the } \\
\text { private sector due to obligation of selling sugar } \\
\text { at a fixed price }\end{array}$ \\
\hline O4: Valorization of sugar industry wastes & $\begin{array}{l}\text { T4: Government approval for establishing other } \\
\text { factories will affect ability to obtain necessary } \\
\text { funding to attain maximum capacity }\end{array}$ \\
\hline 05: Develop information systems to facilitate & T5: Imports of raw sugar \\
\hline
\end{tabular}

\section{Hierarchical Structure}

AHP is combined with SWOT analysis in this step to illustrate the hierarchical structure of the evaluation process (Figure 2). The upper level represents the goal, the second level represents the strategic objectives (SO), and the lowest level denotes the factors assigned to each SWOT category. 


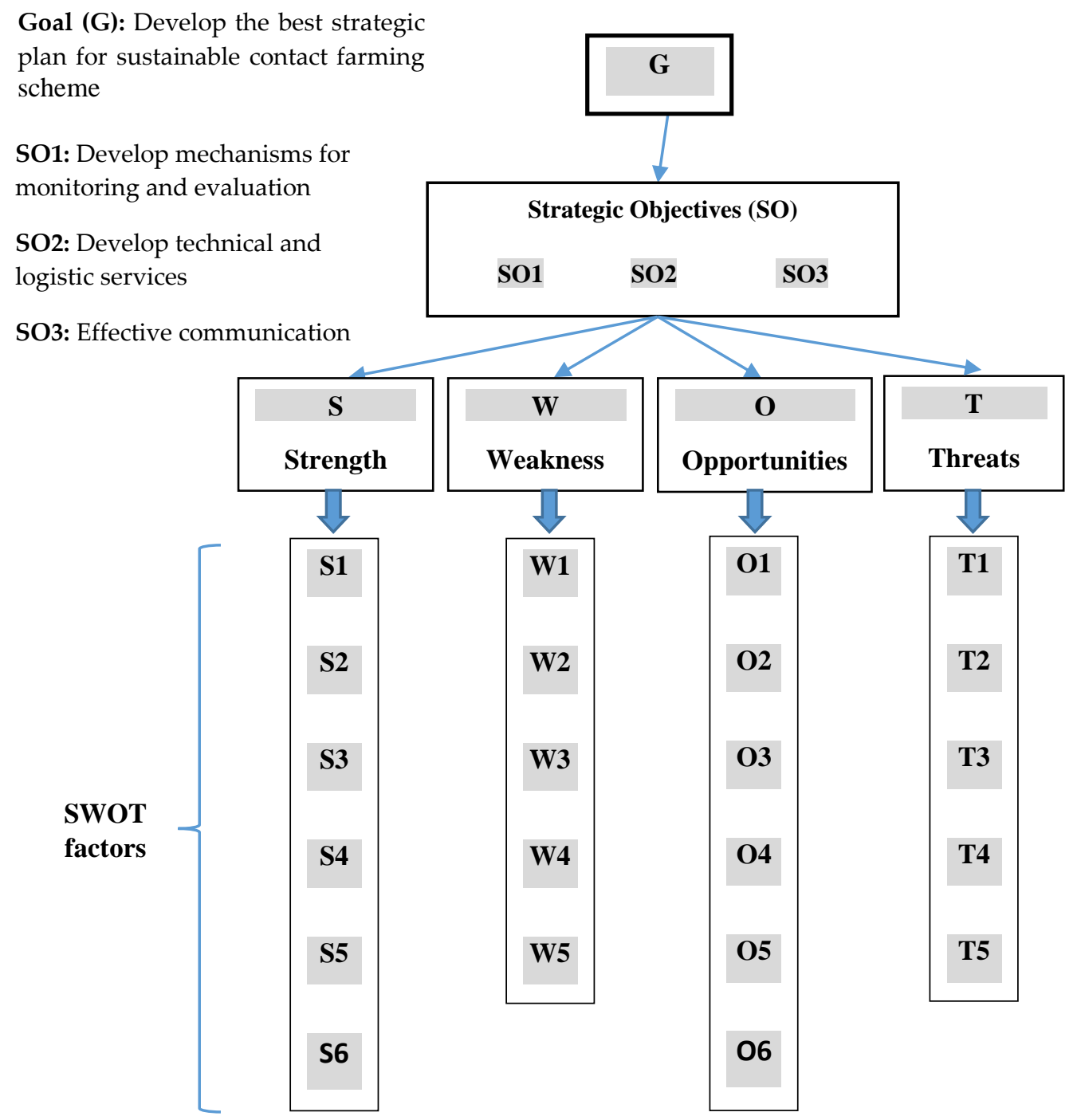

Figure. 2: SWOT factors of contract farming in the sugar sector

\section{Pairwise Comparison}

The comparison matrix is formed at the level of strategic objectives to identify the most significant objective and use its values as a scaling factor. The results in Table 4 show that effective communication (SO3) is the most significant factor with a scaling factor of 0.58 , followed by develop technical and logistic services (SO1), and develop mechanisms for monitoring and evaluation (SO2). The value of CR (0.081) is within acceptable levels, suggesting a good indicator for AHP criteria. Communication plays a critical role in business success as a competitive advantage. Hence, the organizational structure should be adjusted to enhance exchange of information and ideas within the organization (internally) and bringing information from outside into the organization (externally) (Tankosic, Ivetic, and Mikelic, 2017). DSRC should implement policies for sustainable contract services and develop effective information systems for facilitating information flow internally and externally (O5). 
Table 4: Pairwise comparison of SWOT strategic objectives

\begin{tabular}{ccccccc}
\hline $\begin{array}{c}\text { Strategic } \\
\text { Objectives }\end{array}$ & $\begin{array}{c}\text { Develop } \\
\text { technical } \\
\text { and } \\
\text { logistic } \\
\text { services }\end{array}$ & $\begin{array}{c}\text { Develop } \\
\text { mechanisms } \\
\text { for } \\
\text { monitoring } \\
\text { and } \\
\text { evaluation }\end{array}$ & $\begin{array}{c}\text { Effective } \\
\text { communication }\end{array}$ & Total & $\begin{array}{c}\text { Scaling } \\
\text { factor }\end{array}$ & CR \\
\hline $\begin{array}{c}\text { Develop } \\
\text { technical and } \\
\text { logistic }\end{array}$ & 0.3 & 0.33 & 0.29 & 0.93 & 0.31 \\
$\begin{array}{c}\text { services (SO1) } \\
\text { Develop } \\
\text { mechanisms } \\
\text { for monitoring } \\
\text { and evaluation } \\
\begin{array}{c}\text { (SO2) } \\
\text { Effective }\end{array}\end{array}$ & 0.09 & 0.11 & 0.12 & 0.32 & 0.11 & 0.081 \\
$\begin{array}{c}\text { communication } \\
\text { (SO3) }\end{array}$ & 0.61 & 0.56 & 0.59 & 1.75 & 0.58 & \\
\hline
\end{tabular}

The next level of pairwise comparisons was tested between the factors in each SWOT group. The AHP results reveal that decision makers consider opportunities to be the most important, followed by strengths, threats, and weaknesses (see Table 5). Opportunities are approximately twice more important than strengths and thrice more than threats. The results reflect that the company is presented with many opportunities and should use its strengths to minimize the risks of weaknesses and threats.

Table 5: Pairwise comparison of SWOT factors

\begin{tabular}{cccccc}
\hline SWOT groups & Strengths & Weaknesses & Opportunities & Threats & $\begin{array}{c}\text { Priority } \\
\text { within group } \\
\text { (Scaling } \\
\text { factor) }\end{array}$ \\
\hline Strengths & 0.14 & 0.25 & 0.6 & 0.05 & 0.241 \\
Weaknesses & 0.03 & 0.05 & 0.03 & 0.03 & 0.114 \\
Opportunities & 0.42 & 0.45 & 0.3 & 0.77 & 0.487 \\
Threats & 0.42 & 0.25 & 0.06 & 0.15 & 0.158 \\
\hline
\end{tabular}

Based on the AHP outcome, reduced market risk due to forward contracting is adjudged the top priority among strengths. To consolidate this strength, there is a need for designing mechanisms for managing conflict with farmers (O3) and implementing the suggested sustainable plan $(\mathrm{O} 2)$ to ensure that the major threat to the sugar industry (sustainable production; T1) is effectively curtailed. The success of contract farming as a business model between farmers and agro-industrial firms is determined by different factors, such as level of conflict, commitment, trust, and expectations of continuity (Huang Anh, Bokelmann, Thi Thuan, Do Nga, Van Minh, 2019). 
Non-commitment of farmers to harvest time (W1) was adjudged the highest rated factor among weaknesses. Sugar beet is sown in the study area on different dates (from August 15th to October 15th) depending on to the harvest time of the previous crop. Some of the farmers who sow sugar beet late do not follow the extension recommendations of the company regarding the harvest date as they want to harvest the summer crops on time. Furthermore, the delay in transportation of the crop after harvest by the company (W3) could be another reason for this weakness. To reduce the effect of this weakness, the number of transportation vehicles should be increased and an executive plan in cooperation with the farmers should be developed to accurately consider the quantity to be transported, number of farmers in each block, and date of harvest. This is supported by Fishpool (2016) that states that transportation problems in the sugar sector could be reduced by increasing storage capacity and number of trucks in the harvest season.

Regarding the prioritization of opportunities, valorization of sugar industry wastes is ranked first. Waste management is essential for the sugar industry as an additional revenue source and for reducing the impact on human health and environment during sugar processing (Rajaeifar et al., 2019). Sugar waste management minimizes the risk of accumulating large reserves of sugar at the factory premises (T2) and increases sugar supply through the establishment of other factories (T4). This also includes producing energy from sugar industry by-products (bagasse and straw); conducting thermochemical conversion (hydrogen generation, production of bio-oil, value-added chemicals, production of bio-char) of the by-products; producing ethanol (as an alternative fuel), paper, dry yeast, alcohol, vinegar, and aromatic pastries; and utilizing secondary by-products in the construction sector (Gopinath, Bahurudeen, Appari, and Nanthagopalan, 2018).

Accumulation of large reserves of sugar is the top priority among the threats. This could be because the Egyptian government imposes a fixed sale price for the sugar produced by government-owned companies (Omar, 2019). This decreases the capability of public companies to compete with private sugar companies. Importing sugar because of decreasing sugar prices in the international markets could be another reason for this threat. The largest sugar exporting countries, particularly India, provide price subsidies to maintain their export position in the international sugar markets at 20\%, which in turn has led to a decrease in prices over 2017-2019 (World Trade Organization, 2019). This threat has a negative effect on achieving the optimum manufacturing capacity (O6). Therefore, a special interest in other opportunities, such as developing a sustainable plan $(\mathrm{O} 2)$ is important. This plan includes the possibility of reducing production and transaction costs associated with the sugar industry and reformulating the price policy in cooperation with the sugar committee to empower public sugar companies in sustainable production.

\section{Evaluation of the hierarchical structure (SWOT model)}

After analysing the priority scores among the SWOT sub-factors, a final analysis is performed for the priority weights of their overall priority values within the SWOT categories (Table 6). The results show that the priority order of the factors is: valorization of sugar industry wastes $(\mathrm{O} 4)$, reduced market risk due to forward contracting (S1), accumulation of large reserves of sugar (T2), and non-commitment of farmers to harvest time (W1). 
Table 6: Factor priority scores and overall priority scores of SWOT factors

\begin{tabular}{|c|c|c|c|c|c|}
\hline $\begin{array}{l}\text { SWOT } \\
\text { groups }\end{array}$ & $\begin{array}{l}\text { Group } \\
\text { priority }\end{array}$ & $\begin{array}{l}\text { SWOT } \\
\text { factors }\end{array}$ & CR & $\begin{array}{l}\text { Priority of } \\
\text { factor within } \\
\text { group }\end{array}$ & $\begin{array}{c}\text { Overall } \\
\text { priority of } \\
\text { factor }\end{array}$ \\
\hline \multirow{6}{*}{ Strengths } & \multirow{6}{*}{0.26} & S1 & \multirow{6}{*}{0.068} & 0.32 & 0.083 \\
\hline & & S2 & & 0.08 & 0.021 \\
\hline & & S3 & & 0.09 & 0.023 \\
\hline & & S4 & & 0.05 & 0.013 \\
\hline & & S5 & & 0.26 & 0.068 \\
\hline & & S6 & & 0.02 & 0.005 \\
\hline \multirow{7}{*}{ Weaknesses } & \multirow{6}{*}{0.04} & $=4.164$ & \multicolumn{2}{|c|}{$\mathrm{Cl}=0.054$} & \\
\hline & & W1 & & 0.37 & 0.015 \\
\hline & & W2 & & 0.11 & 0.004 \\
\hline & & W3 & 0.071 & 0.21 & 0.008 \\
\hline & & W4 & & 0.04 & 0.002 \\
\hline & & W5 & & 0.02 & 0.001 \\
\hline & & $=4.13$ & $\mathrm{Cl}=$ & & \\
\hline \multirow{6}{*}{ Opportunities } & \multirow{6}{*}{0.48} & 01 & \multirow{6}{*}{0.082} & 0.01 & 0.005 \\
\hline & & $\mathrm{O} 2$ & & 0.16 & 0.077 \\
\hline & & $\mathrm{O} 3$ & & 0.12 & 0.058 \\
\hline & & $\mathrm{O} 4$ & & 0.28 & 0.134 \\
\hline & & O5 & & 0.03 & 0.014 \\
\hline & & $\mathrm{O} 6$ & & 0.06 & 0.029 \\
\hline \multirow{7}{*}{ Threats } & \multirow{7}{*}{0.22} & $=4.25$ & \multirow[t]{3}{*}{$\mathrm{Cl}=\mathrm{C}$} & & \\
\hline & & $\mathrm{T} 1$ & & 0.04 & 0.009 \\
\hline & & T2 & & 0.35 & 0.077 \\
\hline & & T3 & 0.092 & 0.27 & 0.059 \\
\hline & & $\mathrm{T} 4$ & & 0.19 & 0.042 \\
\hline & & T5 & \multirow{2}{*}{\multicolumn{2}{|c|}{$\mathrm{Cl}=0.087$}} & 0.026 \\
\hline & & $=4.26$ & & & \\
\hline
\end{tabular}

\section{Conclusion and Recommendation}

The strategic planning approach to the development of contract farming in the Egyptian sugar industry is based on four main components. First, supporting investments for valorization of sugar industry wastes. Second, suggesting plans for minimizing the risk of accumulation of large reserves of sugar. Third, increasing the maximum capacity of sugar factories to increase number of contract farmers. Fourth, increasing awareness of commitment to harvest time among contract farmers. These strategies could be used for orienting future investments in the Egyptian sugar sector and to determine interventions for creating a sustainable supply chain.

\section{References}

Abdollahzadeh, G., C.A. Damalas, M.S. Sharifzadeh and H. Ahmadi-Gorgi. (2016). Selecting strategies for rice stem borer management using the Analytic Hierarchy Process (AHP). Crop Protection, 84, 27-36.

Ba, H.A., Y. de Mey, S. Thoron and M. Demont. (2019). Inclusiveness of contract farming along the vertical coordination continuum: Evidence from the Vietnamese rice sector. Land Use Policy, 87, 104050.

Biely, K., S. Creemers, S. Van Passel and E. Mathijs. (2018). Report of Sustainable finance for sustainable agriculture and fisheries project (SUFISA), EU. 
DiNicolantonio, J. J. and A. Berger. (2016). Added sugars drive nutrient and energy deficit in obesity: a new paradigm. Open Heart, 3 (2), e000469.

DSRC (Dakahalia Sugar and Refining Company). (2019). Unpublished statistical report of 2018-19 season. DSRC, Dakahalia, Egypt.

Eggleston, G. and I. Lima. (2015). Sustainability issues and opportunities in the sugar and sugar-bioproduct industries. Sustainability, 7 (9), 12209-12235.

Etongo, D., M. Kanninen, T.E. Epule and K. Fobissie. (2018). Assessing the effectiveness of joint forest management in Southern Burkina Faso: A SWOT-AHP analysis. Forest Policy and Economics, 90, 31-38.

Fishpool, P. (2016). Maximising the efficiency of the UK Sugar Beet supply chain. A Nuffield Farming Scholarships Trust Report, UK.

Food and Agriculture Organization of the United Nations (FAO). (2017). The future of food and agriculture - Trends and challenges. FAO, Rome.

Food and Agriculture Organization of the United Nations (FAO). (2019). Food outlook. Biannual report on global food markets, FAO, Rome.

Food and Agriculture Organization of the United Nations statistics (FAOSTAT). (2017). Crop production statistics. FAOSTATE, FAO, Rome.

Gopinath, A., A. Bahurudeen, S. Appari and P. Nanthagopalan. (2018). A circular framework for the valorisation of sugar industry wastes: Review on the industrial symbiosis between sugar, construction and energy industries. Journal of Cleaner Production 203, 89-108.

Gottfried, O., D. De Clercq, E. Blair, X. Weng and C. Wang. (2018). SWOT-AHP-TOWS analysis of private investment behavior in the Chinese biogas sector. Journal of Cleaner Production, 184, 632- 647.

Hung Anh, N., W. Bokelmann, N. Thi Thuan, T. Do Nga and N. Van Minh. (2019). Smallholders' preferences for different contract farming models: Empirical evidence from sustainable certified coffee production in Vietnam. Sustainability, 11 (14), 3799.

Khan, M.F., Y. Nakano and T. Kurosaki. (2019). Impact of contract farming on land productivity and income of maize and potato growers in Pakistan. Food Policy, 85, 2839.

Lambrecht, I. B. and Ragasa, C. (2018). Do development projects crowd-out private sector activities? Evidence from contract farming participation in Northern Ghana. Food Policy, 74, 9-22.

Ministry of Agriculture and Land Reclamation (MALR). (2019). Sugar annual report. MALR, Cairo.

Mu, E. and M. Pereyra-Rojas. (2017). Practical decision making: An introduction to the Analytic Hierarchy Process (AHP) using super decisions V2. In: Springer Briefs in Operational Research, Springer Nature, Berlin.

Omar, S.R. (2019). Egypt sugar annual increasing sugar supply on expanded beet production. Sugar annual. GAIN Report Number: EG-19006. USDA, Washington, D.C.

Omobepade, B.P., O.T. Adebayo and T.T. Amos. (2019). Modeling White Shrimp (Nematopalaemon hastatus) value chain using combined SWOT and AHP. Int. J. Food System Dynamics, 10 (2), 206-223.

Phadermrod, B., R.M. Crowder and G.B. Wills. (2019). Importance-performance analysis based SWOT analysis. International Journal of Information Management, 44, 194-203.

Polat, Z.A., M. Alkan and H.G. Sürmeneli. (2017). Determining strategies for the cadastre 2034 vision using an AHP-Based SWOT analysis: A case study for the Turkish cadastral and land administration system. Land Use Policy, 67, 151-166.

Ragasa, C., I. Lambrecht and D.S. Kufoalor. (2018). Limitations of contract farming as a propoor strategy: The case of maize outgrower schemes in Upper West Ghana. World Development, 102, 30-56. 
Rajaeifar, M.A., S.S. Hemayati, M. Tabatabaei, M. Aghbashlo, and S.B. Mahmoudi. (2019). A review on beet sugar industry with a focus on implementation of waste-to-energy strategy for power supply. Renewable and Sustainable Energy Reviews, 103, 423-442.

Soullier, G. and P. Moustier. (2018). Impacts of contract farming in domestic grain chains on farmer income and food insecurity. Contrasted evidence from Senegal. Food Policy, 79, $179-198$.

Szulecka, J. and E.M. Zalazar. (2017). Forest plantations in Paraguay: Historical developments and a critical diagnosis in a SWOT-AHP framework. Land Use Policy, 60, 384-394.

Tankosic, M., P. Ivetic and K. Mikelic. (2017). Managing internal and external Communication in a Competitive Climate via EDI concept. International Journal of Communications, 2, 1-8.

Ton, G., W. Vellema, S. Desiere, S. Weituschat and M. D'Haese. (2018). Contract farming for improving smallholder incomes: What can we learn from effectiveness studies?. World Development, 104, 46-64.

United States Department of Agriculture (USDA). (2019). Global sugar production up slightly in 2019/20: Gains in Brazil and European Union offset declines in India. Sugar: World Markets and Trade, USDA, Washington, D.C.

World Trade Organization. (2019). India: Measures concerning sugar and sugarcane. Discussion paper (19-4741), WTO, Geneva, Switzerland.

$\mathrm{Yu}, \mathrm{J}$. and Wu, J. (2018). The sustainability of agricultural development in China: The agriculture - environment nexus. Sustainability, 10, 1776.

Ze-ying, H., X. Ying, Z. Di, W. Chen and W. Ji-min. (2018). One size fits all?: Contract farming among broiler producers in China. Journal of Integrative Agriculture, 17 (2), 473482. 